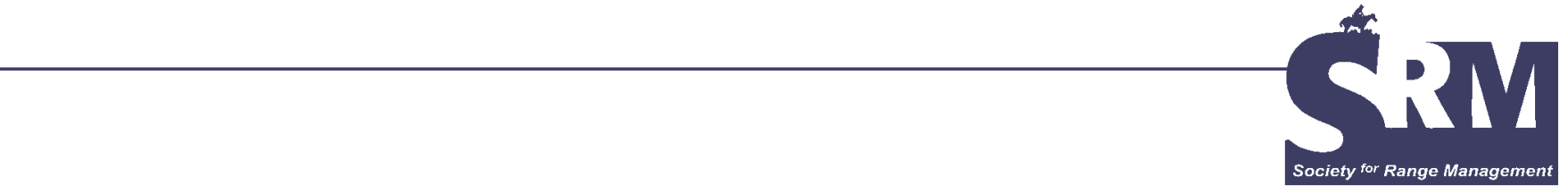

\title{
Fifth in a Series: Insight From SRM's Charter Members
}

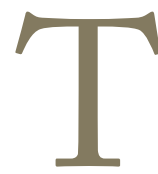
he Society for Range Management (SRM) History Committee has conducted interviews with many of the Society's charter members to capture their perspective of events leading to and subsequent to the formation of the American Society of Range Management in 1947-1948. Interviews from several of these individuals will be shared for today's SRM members to enjoy and learn from.

\section{SRM Charter Member - Paul F. Gilbert}

Editor's Note: Bill Hurst conducted a telephone interview with Paul Gilbert on March 4, 2004. Paul can be reached at PO Box 24, Hot Sulphur Springs, CO 80451.

I am 88 years old. I was born in Colorado Springs, Colorado, in 1915. My father was a district forest ranger with the US Forest Service on the San Isabel National Forest, so I was raised in a Forest Service family and early on in my life I had aspirations of becoming a member of that organization.

I graduated from Colorado State University in 1940 with a degree in forestry. During this period I worked 3 seasons for the Forest Service as a member of a range survey crew on the Pike, San Isabel, Roosevelt, and Cochetopa national forests.

During World War II, I served 4 years in the Army, 1942-1946. After discharge from the military in 1946 I went to work with the Colorado Game and Fish Department and completed a 32-year career with that organization, retiring in 1973. In setting big game hunting seasons during this period of time, the recommendations of the field men had to include an assessment of winter range conditions. These ranges were and are critical to the welfare of big game animals.

In 1948 I joined the American Society of Range Management (ASRM) as a charter member. Clint Wasser was responsible for acquainting me with this budding organization and encouraging me to join. I was in full agreement with the objectives of the new Society. At that time I thought that both the national forests and the public domain were being overused by domestic livestock, and I was hopeful the ASRM would be helpful in encouraging better management by all concerned. In this respect I believe my expectations for the Society have been fulfilled.

I believe the Society has stayed on track over the years and has improved its programs and its influence. I am proud to be a member and to have been a part of the organization since its beginning.

I have never served in any major office in the Society but have been a faithful member since its inception.

\section{SRM Charter Member - Howard R. DeLano}

Editor's Note: Tom Bedell compiled the information mailed to bim in February 2003. Howard DeLano lives with his wife, Pearl, at 17572 S. Hattan Rd., Oregon City, OR 97045.

I was born July 4, 1913. I retired from the Bureau of Land Management (BLM) in 1972 after 33 years with the federal government, including 3 years in the US Navy during World War II. I now own and operate DeLano Farms, LLC. During 1947 and 1948 when the ASRM was organized I was employed as a range conservationist with BLM at Vale, Oregon. I was assistant district manager and largely involved in range adjudication work.

I graduated from Oregon State College (OSC) with a major in forestry and a minor in range management. My range management professor was R.G. Johnson, who started the range courses at OSC. I worked on range surveys with the US Forest Service (USFS) in the summer of 1937. In the latter part of the summer I worked on approving range project work for the Agriculture Adjustment Administration. This work created further interest in range management work.

I became acquainted with Joe Pechanec of the USFS and other people interested in range management. I met with an 
organizing group for the ASRM in Pendleton, Oregon, and joined the group. As I remember that was sometime in 1947. I was on the program for the first section meeting that was in Baker, Oregon. My subject was "The Establishment of Grazing Allotments and Developing Management Plans.” I joined the Pacific Northwest Section of the ASRM when it first started, which must have been about 1948. I have been a member of this section ever since.

I did not attend the first meeting in Salt Lake City. However, someone sent me records of this meeting. I remember John Clouston sending me some information but I do not remember exactly when.

In $1948 \mathrm{I}$ expected the ASRM to provide support for good range management and to educate people on the subject. I hoped it would provide a means for various interests to exchange ideas and cooperate in the use, protection, and improvement of rangelands resources. The ASRM has been very helpful in these endeavors.

After graduating from Oregon City High School in 1930, I did farm work and was a telephone lineman for the local telephone company. I started college at OSC in 1935 and received my BS degree in forestry. My first summer work while attending OSC was as a fire lookout for the 1936 summer on Black Butte in the Shasta National Forest in California. The summers of 1937 and 1938 were spent largely working on range surveys and some fire fighting. In 1939 I received a civil service appointment as a junior range examiner with the US Grazing Service in Burns, Oregon. That summer I worked on range surveys in the Drewsey Unit. I also worked out of Jordan Valley and Baker for the Grazing Service.

I joined the US Navy in 1942 and received my officer's commission as an ensign. After being moved around a bit, I ended up in the Aleutians as port director for Chernofski, Alaska, the port for Fort Glenn, Unmak Island, which had some 5,000 men. My job included giving sailing orders to mostly cargo ships headed for the Asian theater of war. Chernofski was a turning point for the ships.

After returning to Seattle I was discharged from the Navy. I went back to work for the Grazing Service, which soon became part of the BLM. I worked as assistant district manager in the Vale and Baker Districts. I acted as the district manager of the Jordan Valley District until this office was closed and consolidated with the Vale District. I then acted as district manager of the Vale District while Arch Hanson was in Salt Lake City for about a year having heart surgery.

I was appointed district manager of the Burns District in 1953 and served in that capacity until the fall of 1958 when I became a watershed specialist at the BLM Area Office in Portland. The area encompassed California, Oregon, and Washington. In 1960 I was appointed chief of Range, Watershed, and Wildlife for the Oregon-Washington state office. One of the highlights of my term in this job was to establish positions in Wildlife, Hydrology, and Soils and to hire men with doctorates in each of these specialties.

During my work in the area and state offices in Portland
I was encouraged to participate in ASRM activities. I served as president of the Portland chapter and also the president of the Pacific Northwest Section. I served as vice chairman and later as chairman of the Range Equipment Committee of the national group. I attended most of the national meetings during the time I worked out of Portland. I also served time as president of the Portland chapter of the American Society of Soil Conservation. I retired from the BLM in July 1972.

From 1958 to the present time I have been actively raising registered beef cattle and farming. I now operate and manage 302 acres of farm and forest land in Clackamas County, Oregon. I served as president of the Clackamas County Livestock Association and as a vice president of the Oregon Cattleman's Association. I have also served as president of the Oregon Polled Hereford Association and president of the Oregon Gelbvieh Association. We have shown our cattle at the various fairs. We have had the Gelbvieh Cow-Calf Champion at the Calgary Stampede (Canada), the Supreme Champion Gelbvieh female at both the Cow Palace (California) and the Northern Inland Livestock Exposition in Billings, Montana. We have had the Grand Champion Gelbvieh bull 3 times at the Oregon State Fair along with many other winnings. We have operated over 80 registered cows in our herd but are now down to 43 registered Gelbvieh cows.

The SRM has overall performed a good job. Its members have been largely employees of government agencies and university people. It would strengthen the Society if more of the private sector were members, including wildlife, livestock, and business interests.

Interested young people should include range management as part of their studies in high school, and even in grade school.

\section{SRM Charter Member - Weldon O. Shepherd}

Editor's Note: Weldon O. Shepherd lives at 203 Tuxedo Drive, Thomasville, GA 31792.

I had been working for the Forest Service for about 7 years when the American Society of Range Management was organized in 1948. My work was with the Southeastern Research Station at Tifton, Georgia, and Raleigh, North Carolina. It seemed important that I participate in this new organization.

Anyone raised in Utah cannot help but be interested in land and water conservation. After graduating from high school in Nephi, Utah, I attended Brigham Young University for 1 year and then went to Utah State University, where I received a BS in forestry in 1937. Working toward graduate degrees, I received an MS in 1939 and a PhD in 1951 from the University of Nebraska. During this period I had the opportunity to do some research and to cooperate with other universities. Some of the work started in Nebraska was a survey of Sandhills rangeland and game management. At Colorado State I was interested in foothill and mountain meadow ranges. A brief period at Wisconsin was spent assist- 
ing in instruction in forage crops and pasture management.

In 1940 I took a position with the USFS at Tifton, Georgia, where my research concerned tree-forage relationships on grazed forestland. This involved establishing experimental plots and studying density and species composition, forage types, poisonous plants, and range conditions in Ponderosa pine-cane type areas. The years 1942-1945 were spent in the US Navy Joint Intelligence. During this period I worked with Dick Hurd, also a charter member on the Society for Range Management.

Upon my return to the Southeastern Station I spent 6 years as a forest ecologist concerned with grazing in relation to timber management, watershed protection, timber production, and fire control. In 1952 I became chief of the Range Division in the Southeastern Forest Experimental Station.

After 1951, I served as assistant director of the Division of Range Research in the Washington, DC, office of the Forest Service, where I worked with Division Chief Joe
Pechanec, a familiar name in the Society for Range Management. Later I moved to Ogden, Utah, as director of the Division of Range Research in the Intermountain Forest and Range Experimental Station.

In 1966 I accepted a position with Food and Agriculture Organization of the United Nations as an agricultural officer for range management in Sudan. This involved evaluating existing programs and establishing teaching programs for new institutions there.

I have not been able to be active in the Society for Range Management to any great degree since retirement in 1973. However, reading the journal impresses me with the many students who are featured. Most of my work was in close cooperation with universities, so I feel the importance of passing on the information we gather.

One very important part of SRM was the friendships formed. We forged firm friendships that have meant a great deal to us over the years. 